Вісник Львівського торговельно-економічного університету. Технічні науки. 2019. Вип. 22.

\title{
УДК 10.5604/01.3001.0012.2537
}

Лавінска К.,

к.т.н., Науково-дослідна мережа Лукасевич Інститут шкіряної промисловості, м. Лодзь, Республіка Польщза

Попович H.,

ORCID ID: 0000-0002-4407-105X, Researcher ID: F-7230-2019,

к.т.н., дои., доцент кафедри товарознавства та експертизи в митній справі, Львівський торговельно-економічний університет, м. Львів,

Науково-дослідна мережа Лукасевич - Інститут шкіряної промисловості, м. Лодзь, Республіка Польща

Сервета B.,

к.т.н., Науково-дослідна мережа Лукасевич - Інститут шкіряної промисловості, м. Лодзь, Республіка Польщза

Стефаник М.,

здобувач, Львівський торговельно-економічний університет, м. Львів

\section{ДОСЛІДЖЕННЯ ПОКАЗНИКІВ БЕЗПЕЧНОСТІ ВЗУТТЄВИХ ТЕКСТИЛЬНИХ МАТЕРІАЛІВ 3 БАМБУКОВИХ ВОЛОКОН}

\begin{abstract}
Анотація. Обтрунтовано актуальність проблеми безпечності вихідних матеріалів для виготовлення взуття та одягу, зокрема дитячого, в контексті ймовірної міграції шкідливих сполук в організм дитини. Викладені практичні аргументи, які доводять невідкладність процесу розробки вимог до використання хімічно нестабільних матеріалів і/чи речовин у матеріалах для дитячого взуття. Доведено, шчо проблема розробки сучасного безпечного взуття для дітей має комплексний характер і може бути успішно вирішена лише реалізачією науково обтрунтованих вимог як до безпечності його конструкиї, так $і$ до безпечності вихідних матеріалів. Досліджено окремі показники безпечності текстильних матеріалів з бамбукових волокон, призначених для виготовлення дитячого взуття.
\end{abstract}

Ключові слова: дитяче взуття, властивості, текстильні матеріали, безпечність.

Lawinska K.,

Ph.D., Lukasiewicz Research Network - Institute of Leather Industry, Lodz,

Republic of Poland

Popovych N.,

ORCID ID: 0000-0002-4407-105X, Researcher ID: F-7230-2019,

Ph.D, Associate Professor, Associate Professor of the Department of Commodity Studies and Expertise in Customs, Lviv University of Trade and Economics, Lviv, Ukraine, Łukasiewicz Research Network - Institute of Leather Industry, Lodz,

Republic of Poland

Serweta $W$.,

Ph.D., Lukasiewicz Research Network - Institute of Leather Industry, Lodz,

Republic of Poland

Stefanyk M.,

Postgraduate, Lviv University of Trade and Economics, Lviv, Ukraine 
Вісник Львівського торговельно-економічного університету. Технічні науки. 2019. Вип. 22.

\title{
RESEARCH OF SAFETY INDICATORS OF FOOTWEAR TEXTILE MATERIALS MADE FROM BAMBOO FIBERS
}

\begin{abstract}
The urgency of the problem of the raw materials safety for the manufacturing of footwear and clothing, in particular for children, in the context of the likely migration of harmful compounds into the children's body is substantiated. Practical arguments are outlined that prove the urgency of the process of developing requirements for the use of chemically unstable materials and/or substances in materials for children's footwear. It is proved that the problem of developing modern safe footwear for children is complex in nature and can be successfully solved only by the introduction of scientifically substantiated requirements both for the safety of its design and for the safety of raw materials. Separate safety indicators of textile materials made from bamboo fibers intended for the manufacturing of children's footwear have been investigated.
\end{abstract}

Key words: children's footwear, properties, textile materials, safety.

JEL Classification: L15; L60

DOI: https://doi.org/10.36477/2522-1221-2019-22-03

Постановка проблеми. Відомо, що натуральна шкіра досі залишається найкращим (за комплексом споживних властивостей) матеріалом для виготовлення багатьох елементів (вузлів, деталей) взуття, в тому числі і дитячого, оскільки, зокрема, завдяки хімічному складу та структурі - має хороші характеристики паропроникності, здатності поглинати i десорбувати вологу, а також механічних властивостей $[1 ; 2]$. Однак під дією поту, який виділяє стопа, та бруду, з яким взуття неодмінно стикається під час експлуатації, натуральна шкіра відносно швидко втрачає рівень споживних властивостей [1;2]. Крім того, постійно зростаючі ціни на натуральну шкіру вимагають пошуку нових рішень, які б дали змогу зменшити дію означених чинників [1;2]. Як результат, для виготовлення взуття використовуються різні синтетичні замінники, які часто мають позитивні відмінності від натуральної шкіри: так, на ринку вихідних взуттєвих матеріалів 3'являються все нові синтетичні матеріали як альтернатива натуральній шкірі з точки зору дизайну та технології [1;2].

Аналіз закордонних публікацій показує $[1 ; 2]$, що текстильні матеріали (з достатньою стійкістю до стирання, сорбції-десорбції, паропроникності тощо) для внутрішніх елементів взуття провідні виробники традиційно вибирають за призначенням взуття. Найчастіше використовують тканини і трикотажні полотна 3 різною часткою вмісту натуральних волокон у поєднанні 3 нетканими матеріалами, як правило - 3 синтетичних волокон. Тому зростають значення i масштаби використання синтетичних матеріалів 3 просторовою структурою, яка забезпечує поглинання значної кількості вологи.

Наприклад, для внутрішніх елементів взуття використовують мембранні матеріали на основі синтетичних волокон (відомими матеріалами $\epsilon$ Sympatex, Tepor-Tex, Gore-Tex), які спроможні забезпечити водонепроникність взуття при збереженні властивостей проникності водяної пари i повітря. Такі матеріали призначені для спортивного, гірського, трекінгового, туристичного взуття та спеціального взуття (зокрема, для збройних сил). Принцип діафрагми також використовується в системі GEOX [1; 2], яка забезпечує вентиляцію стопи через отвори в підошві.

Удосконалення терморегуляційних властивостей взуття забезпечило [1;2] використання у внутрішніх елементах матеріалів для модифікації їх фаз (фазових матеріалів-14, терморегуляторних текстильних виробів), які поглинають або вивільняють тепло залежно від зміни параметрів навколишнього середовища і рівня фізичної активності людини (наприклад, використані для цієї мети поліакрилові волокна можуть поглинати вологи в 3,5 рази більше, ніж бавовна).

Комбінація натуральної шкіри 3 волокном LYCRA забезпечує значний позитивний ефект у створенні комфортного взуття [1;2], а використання для ламінування лаків для покривання шкіри 3 поліуретановими чи ПВХ плівками поліпшує зовнішній вигляд натуральної шкіри, але знижує рівень ії гігієнічних властивостей $[1 ; 2]$.

Комфортність використання взуття сьогодні стає дедалі вагомішою властивістю у комплексній оцінці його якості. При такій оцінці розрізняють комфорт механічний i фізіологічний: механічний комфорт (зручність у процесі експлуатації і антропометрична відповідність взуття) $є$ суб'єктивною оцінкою споживача, а фізіологічний комфорт характеризують оцінкою мікроклімату всередині взуття. Тому гігієнічність взуття та матеріалів для його виробництва - це можливість забезпечити потрібний мікроклімат під час його використання, а також це вирішальні чинники для оцінки якості функціональних та експлуатаційних властивостей взуття.

Означені напрями покращення споживних властивостей взугтя сьогодні неодмінно аналізують у контексті безпечності, котру сьогодні розуміють як відсутність будь-якого ризику для життя, здоров'я людини при звичайних умовах використання, зберігання [3]. Тому в сучасному конкурентному середовищі світового ринку особливо вагомі не лише класичні вимоги до якості продукції, але й вимоги до її безпечності. Зокрема, в кожній країні Євросоюзу найважливішою вимогою до ужиткових товарів $\epsilon$ екологічна безпечність продукції, яка, серед іншого, передбачає: відсутність у готовому до вжитку виробі речовин, які 
негативно впливають на організм людини; безпечність використання (вилучення) сировинних ресурсів для людини та навколишнього середовища; мінімальний негативний вплив на всіх етапах виробництва продукції; нешкідливу утилізацію, ефективну переробку промислових відходів [3].

Також відомо, що в Україні серед підгалузей виробництва одягу і взуття найбільш екологічно небезпечні текстильна, шкіряно-взуттєва, хутряна і шкіргалантерейна. Зокрема, взуттєві матеріали i вихідна сировина для їх виготовлення можуть бути потенційним джерелом негативного впливу комплексу хімічних речовин, які можуть спричиняти різні біологічні ефекти, мають різні класи небезпечності та призначення у комплексі виробництва продукції.

Особливу актуальність проблеми безпечності вихідних матеріалів для взуття та одягу обгрунтовує i те, що людина безпосередньо контактує 3 цими матеріалами у виробах 3 моменту народження, а також те, що сполуки, які містяться у даних матеріалах, спроможні мігрувати в організм [3].

Аналіз останніх досліджень і публікацій. Вагомий внесок у формування науково обгрунтованих вимог до взуття для дітей в Україні у 19802010 рр. зроблено у наукових школах професорів Л. Байдакової, І. Дудли, Е. Касьяна, В. Коновала, О. Мокроусової, Н. Омельченко (Київ), Н. Омельченко (Полтава), Б. Семака-старшого та ін., але в останні роки дані про подальші дослідження відсутні. У Польщі найвагоміші роботи науковців, присвячені цим проблемам, опублікували у науководослідному інституті IPS (Instytut Przemysłu Skórzanego) у м. Лодзь і його відділення у м. Краків - це A. Bednarska, R. Gajewski, E. Grzesiak, K. Lawińska, Zb. Olejnicza, B. Rajchel-Chyla, W. Serweta, B. Woźniak, E. Wozniak. Але публікації за результатами дослідження показників безпечності текстильних матеріалів з бамбукових волокон у доступних джерелах відсутні.

Постановка завдання. Метою даної публікації $\epsilon$ викладення й аналіз отриманих авторами результатів дослідження безпечності текстильних матеріалів з бамбукових волокон, призначених для виготовлення дитячого взуття.

Виклад основного матеріалу дослідження. Результати досліджень ринку розвинених країн Свропи показують, що сегмент дитячого одягу i взуття є найбільш масштабним і таким, що найбільш динамічно розвивається на ринку дитячих товарів. А через постійно зростаючу обізнаність і поінформованість суспільства аспект безпеки використання цих товарів може бути одним із найважливіших критеріїв формування їх асортименту [4].

Зокрема, за результатами аналізу літературних даних нами зроблено висновок: базовим у виробництві сучасного взуття для дітей $\epsilon$ думка науковців про те, що стопа дитини - це мініатюрне відображення стопи дорослої людини $[5,6]$, а еволюція дитячої стопи - спрямована на розробку механізму біомеханічного забезпечення організму, який дає можливість стопі здійснювати усі природні процеси (забезпечувати стояння, ходьбу, біг, стрибки тощо) [7]. Найважливіший період, в який формується стопа, припадає на дошкільний і ранній шкільний вік, до досягнення дитячою стопою форми дорослої стопи (приблизно між 12 і 14 роками). Важливою складовою формування стопи $є$ факт посиленого виділення поту залежно від інтенсивності рухливості після прискореного розвитку м'язової системи, особливо у дітей між другим i третім та між сьомим і дванадцятим роком життя [7].

Ми вважаємо, що особливо важливо сформулювати науково обгрунтовані вимоги до матеріалів для виготовлення дитячого взуття на основі праць провідних профільних вчених [8-12], а етап проектування взуття - базувати на наборі параметрів, які забезпечують підтримування природного розвитку і формування м'яких тканин стопи.

Для відповідності цим вимогам температурний діапазон всередині дитячого взуття обрано в інтервалі 21-33 ${ }^{\circ} \mathrm{C}$, а вміст вуглекислого газу всередині взуття - не більше 0,8 проміле за об'ємом. При цьому береться до уваги, що при нормальних фізичних навантаженнях швидкість виділення поту стопою залишається на рівні 3-6 грамів на годину, що безпосередньо залежить від рівня інтенсивності фізичних навантажень та умов зовнішнього середовища, а в крайньому випадку вона може зростати до 20 г на годину [8].

Перші три параметри формування вимог до матеріалу для внутрішніх деталей дитячого взуття ми брали такі, що визначають правильну роботу механізму видалення поту з поверхні шкіри. Цей механізм ми класифікували за основними процесами: сорбція водяної пари та іiі десорбція в навколишнє середовище; дифузія потовиділення через відкриті пори матеріалу верхньої частини заготовки; висушування матеріалів; прямий обмін повітря 3 навколишнім середовищем під час ходьби, бігу тощо.

Отже, матеріал (або пакет матеріалів), призначений для верхньої частини взуття для дітей, повинен мати водопроникність 1,25-2,5 мг/( $\mathrm{cm}^{2} \times$ год.) [8], але, якщо наявне поглинання водяної пари, то забезпечуються комфортні умови при водопроникності менше $5 \mathrm{mг} /\left(\mathrm{cm}^{2} \times\right.$ Год.).

Оскільки такі характеристики споживних властивостей матеріалів для взуття, як змочуваність, поглинання, проникнення води, визначають гідрофобність і водонепроникність цих матеріалів, то важливо, щоб матеріали, призначені для підкладки та устілки взуття для дітей, передбачали властивість змочуватися та мати хороше водопоглинання.

Експериментально встановлено, що найвищою повітропроникністю відрізнялися чисто бамбукові тканини. На нашу думку, це відбувається тому, що поперечний переріз бамбукового волокна заповнений безліччю мікропор та мікроотворів, які покращують наскрізне проходження потоку повітря. Аналогічні висновки сформульовані у працях Кадапалаями та ін. [13], в яких підтверджено, що проникність водяної пари i повітря зростає зі збільшенням частки бамбукових волокон у досліджуваних тканинах. Венкатеш i співавтори [14] додавали бамбукові волокна до волокон сизалі і це 
призвело до зростання значень показників опору згинання, розтягування, проколювання, а збільшення частки бамбукових волокон до $25 \%$ призвело до значного збільшення коефіцієнта поглинання вологи.

Варто наголосити, що бамбукові волокна мають вищезазначені позитивні властивості без додаткових процесів хімічної обробки, що вкрай важливо при розробці дитячого взуття.

Оскільки бамбук володіє протизапальними, в'яжучими й антисептичними властивостями, а порошковий екстракт стебла бамбука виробляє речовину, яка ідеально підходить для шкіри (лікування дерматологічних захворювань, акне тощо), то у 2013 р. в інституті шкіряної промисловості у Кракові були здійснені мікробіологічні випробування текстильних вставок для взуття, виготовлених 3 волокон бамбука у поєднанні 3 природним калієвим галуном. Така вставка продемонструвала хороший антибактеріальний ефект проти Staphylococcus aureus i Escherichia coli, a також протигрибковий ефект проти патогенних грибів Trichophyton mentagrophytes i Candida albicans.

Наведені вище факти пояснюють легітимність і цілеспрямованість модифікації елементів взуття на основі використання досліджуваних бамбукових тканин, оскільки рослинні екстракти використовуються протягом багатьох років в технології рослинництва шкірних експедицій у вигляді природних дубильних речовин, наприклад гамб'є, квебрахо, каштанового дерева, дерева сумах, валонеа, мімози.

За результатами аналізу літературних даних нами доведено, що проблема розробки сучасного безпечного взуття для дітей має комплексний характер i може бути успішно вирішена лише реалізацією науково обгрунтованих вимог як до безпечності його конструкції, так і до безпечності вихідних матеріалів. Додаткове обгрунтування зазначеного полягає в тому, що при експлуатації взуття на споживача впливають небезпечні хімічні речовини, які часто присутні у вихідних матеріалах. Це актуально не лише для взуття, яке передбачає безпосередній контакт із шкірою стопи (літне, кімнатне тощо), але й для усього іншого взуття, в якому виділений стопою піт контактує 3 хімічними речовинами і з шкірою стопи через шкарпетки. Тому для дітей (особливо - віком до 2 -х років, у яких $\epsilon$ природна звичка пізнання за допомогою смакових рецепторів), проблема шкідливого впливу хімічних речовин є ще більш важливою. 3 огляду на це уже тривалий час актуальна проблема обмеження (аж до заборони) використання хімічних речовин у взутті для дітей (яка, наприклад, успішно вирішена у вимогах до дитячих іграшок). Вагомим практичним аргументом для негайної розробки вимог до використання хімічно нестабільних матеріалів i/чи речовин у взутті для дітей $є$ той факт, що найбільш прогресивні його виробники вже сьогодні різко обмежують це негативне явище, практично підтверджуючи можливість виготовлення взуття без небезпечних речовин. Розробку вимог до наявності (обмеження) у взутті для дітей хімічно небезпечних речовин ми пропонуємо на основі принципів, які використовує Сврокомісія з цивільної відповідальності (CEN) у питаннях догляду за дітьми, зокрема у технічному звіті щодо загальних правил безпеки і хімічної небезпеки (CEN / TR 13387-2, 2015). Наприклад, один 3 регламентів REACH (EC 1907/2006 - “Покращення захисту здоров'я людини та довкілля шляхом кращої та більш ранньої ідентифікації властивих властивостей хімічних речовин”) зобов'язує обмежити або звести до мінімальних показників вміст наступних речовин: канцерогени, токсичні та інші шкідливі хімічні речовини; алкілфеноли та алкілфенолетоксилати; ПАУ; фталати; важкі метали; біоцидні речовини; барвники та первинні ароматичні аміни; формальдегід; сенсибілізуючі речовини; $\mathrm{N}$-нітрозаміни та Nамінокислоти та ін. Для розробки запропонованих вимог ми склали пілотний перелік найбільш поширених речовин, використання яких необхідно обмежити першочергово, оскільки вони найбільш ймовірно можуть бути у складі сучасних вихідних матеріалів дитячого взуття [3]:

1) азобарвники: фарбовані шкіри натуральні та текстильні матеріали не повинні містити жодного 3 22-х заборонених ароматичних амінів;

2) шестивалентний хром - Cr(VI): країни $\mathrm{CC} 3$ 01.05.2015 законодавчо обмежили вміст $\mathrm{Cr}(\mathrm{VI})$ у натуральній шкірі до 3 мг/кг (0,0003\% від маси); окремі країни зробили це ще раніше; надмірний вміст Cr(VI) - найбільш поширена причина вилучення взуття з євроринку, перелік такого взуття і його виробників внесений у спеціальну базу даних RAPEX :

3) полівінілхлорид: наявний у взутті в інших матеріалах ПВХ у своєму складі може містити різні хімічні речовини, використані для його полімеризації, стабілізації, пластифікації тощо, найчастіше - свинець або фталати, допустимий вміст яких обмежений;

4) хімічний елемент $\mathrm{Ni}$ : металеві деталі, аксесуари тощо (застібки “блискавка”, кнопки, пряжки, браслети, ланцюжки та ін.), які безпосередньо і тривалий час контактують зі шкірою,

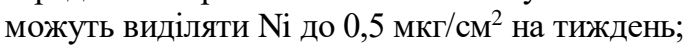

5) перфтороктансульфонат (ПФОС): використовується для надання шкірі та текстилю водостійкості та стійкості до забруднення; його використання в Європі обмежує Постанова ЄС № 850/2004 (Стокгольмська конвенція).

Враховуючи одну з основних вимог до взуття (зокрема, дитячого) - відсутність або наявність у межах ГДК залишків важких металів ( $\mathrm{Sb}, \mathrm{As}, \mathrm{Pb}, \mathrm{Cd}$, $\mathrm{Cr}, \mathrm{Co}, \mathrm{Cu}, \mathrm{Ni}, \mathrm{Hg}$ ), - ми провели попередні випробування вмісту виділених важких металів у текстильних матеріалах для дитячого взуття (рис. 1, табл. 1), оскільки допустиме значення вмісту цих металів - один із ключових чинників впливу на сертифікацію взуття, виготовленого 3 них, для отримання знаку "Здорова стопа" (допустимі значення вмісту означених металів наведені в табл. 2). 
Вісник Львівського торговельно-економічного університету. Технічні науки. 2019. Вип. 22.

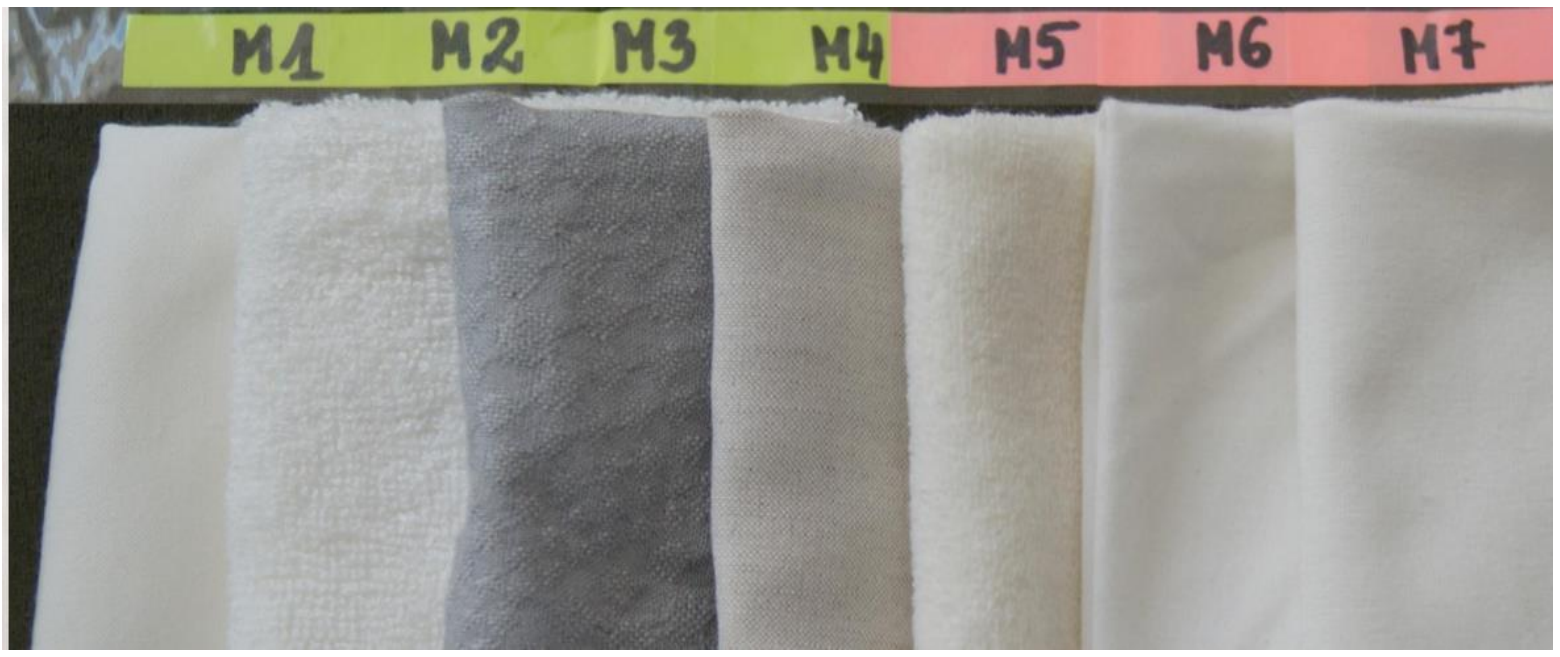

Рис

. 1.

3pa

зки

дос

лід

жув

ани

$\mathbf{x}$

тек

сти

льН

иx

мат

epia

для дитячого взутТя

лів

Таблиияя 1

Характеристика досліджуваних матеріалів для дитячого взуття

\begin{tabular}{|c|c|c|c|c|}
\hline № зразка & Вид матеріалу & Maca, $\Gamma / \mathrm{M}^{2}$ & Товщина, мм & Назва і вміст волокон, \% \\
\hline 1 & Тканина & 170 & 0,40 & Бамбук (100) \\
\hline 2 & Тканина махрова (ворсова) & 500 & 1,74 & Бамбук (100) \\
\hline 3 & Тканина жакардова & 300 & 0,61 & Бамбук:поліестер (95:5) \\
\hline 4 & Тканина & 170 & 0,35 & Бамбук:льон (50:50) \\
\hline 5 & Трикотажне полотно & 290 & 1,20 & Бамбук:поліестер (85:15) \\
\hline 6 & Трикотажне полотно & 220 & 0,38 & Бамбук:еластан (95:5) \\
\hline 7 & Трикотажне полотно & 320 & 0,86 & Бамбук: еластан (97:3) \\
\hline
\end{tabular}

Таблиия 2

Допустимі значення вмісту окремих важких металів

\begin{tabular}{|c|c|c|}
\hline № 3/п & Назва (хімічний символ) металу & Вміст металу, $\mathrm{mg} / \mathrm{kg}$, допустимі значення \\
\hline 1 & Стибій $(\mathrm{Sb})$ & $<30$ \\
\hline 2 & Арсен $(\mathrm{As})$ & $<0,2$ \\
\hline 3 & Свинець $(\mathrm{Pb})$ & $<0,2$ \\
\hline 4 & Кадмій $(\mathrm{Cd})$ & $<0,1$ \\
\hline 5 & Хром $(\mathrm{Cr})$ & $<1$ \\
\hline 6 & Кобальт $(\mathrm{Co})$ & $<25$ \\
\hline 7 & Мідь $(\mathrm{Cu})$ & $<1$ \\
\hline 8 & Нікель $(\mathrm{Ni})$ & $<0,02$ \\
\hline 9 & Ртуть $(\mathrm{Hg})$ & \\
\hline
\end{tabular}

Таблиия 3

Концентрація важких металів у досліджуваних матеріалах

\begin{tabular}{|c|c|c|c|c|c|c|c|c|c|}
\hline \multirow{2}{*}{$\begin{array}{c}\text { № } \\
\text { зразка }\end{array}$} & \multicolumn{10}{|c|}{ Назва і вміст металу, $\mathrm{mg} / \mathrm{kg}$} \\
\hline & Стибій & Арсен & Свинець & Кадмій & Хром & Кобальт & Мідь & Нікель & Ртуть \\
\hline 1 & 0,1372 & $<0,005$ & $<0,01$ & $<0,1$ & $<0,1$ & $<0,1$ & $<0,01$ & $<0,08$ & $<0,1$ \\
\hline 2 & $<0,005$ & $<0,005$ & $<0,01$ & $<0,1$ & $<0,1$ & $<0,1$ & $<0,1$ & $<0,1$ & $<0,1$ \\
\hline 3 & $<0,005$ & $<0,005$ & $<0,01$ & $<0,1$ & $<0,1$ & $<0,1$ & 3,88 & $<0,08$ & $<0,1$ \\
\hline 4 & 0,0952 & $<0,005$ & $<0,01$ & $<0,1$ & $<0,1$ & $<0,1$ & $<0,02$ & $<0,08$ & $<0,1$ \\
\hline 5 & $<0,005$ & $<0,005$ & $<0,01$ & $<0,1$ & $<0,1$ & $<0,1$ & $<0,02$ & $<0,08$ & $<0,1$ \\
\hline 6 & $<0,005$ & $<0,005$ & $<0,01$ & $<0,1$ & $<0,1$ & $<0,1$ & $<0,02$ & $<0,08$ & $<0,1$ \\
\hline 7 & $<0,005$ & $<0,005$ & $<0,01$ & $<0,1$ & $<0,1$ & $<0,1$ & $<0,02$ & $<0,08$ & $<0,1$ \\
\hline
\end{tabular}




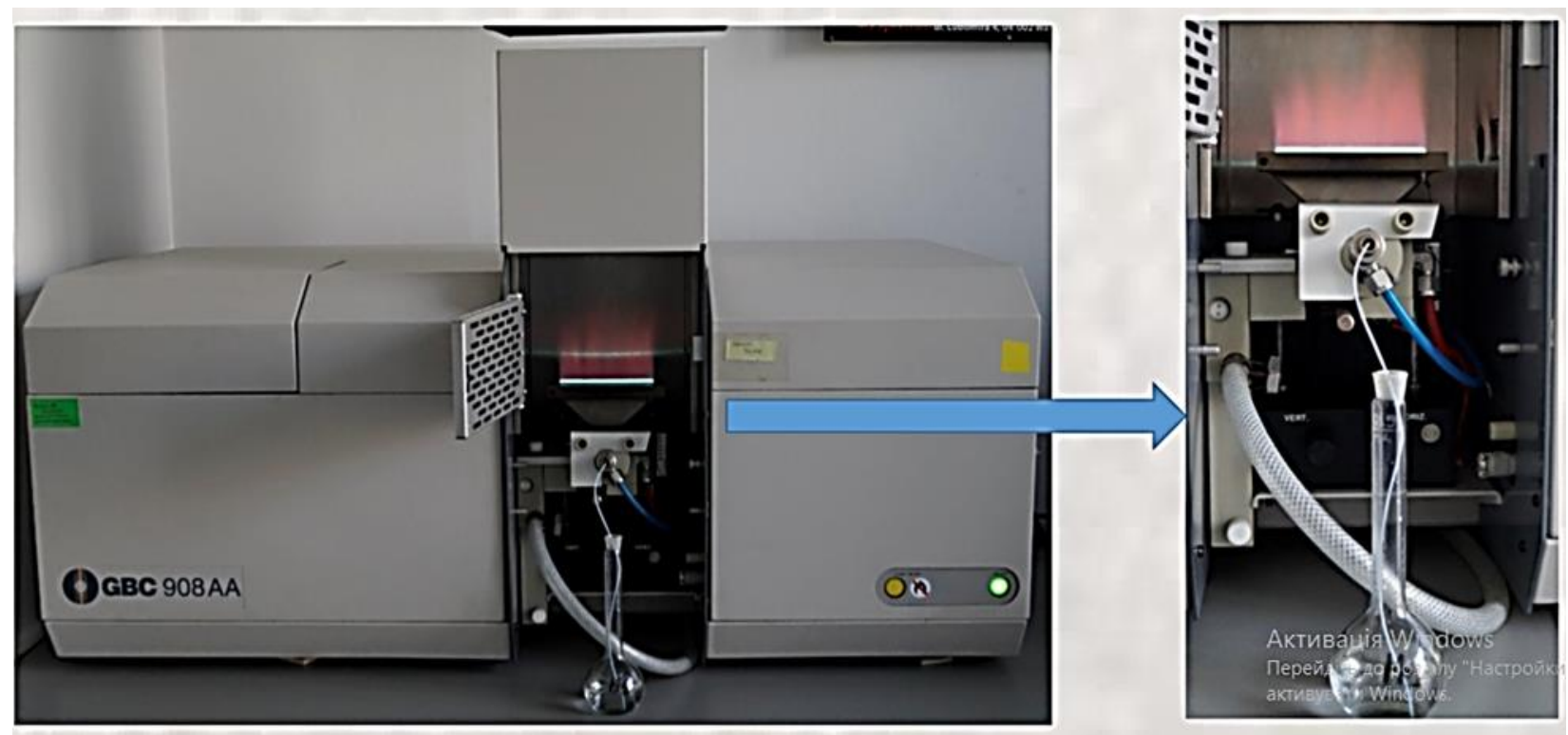

Рис. 2. Прилад GBC 908АA

Дослідження здійснені за методикою PN-EN ISO 17072-1:2011. Шкіра - Хімічне визначення вмісту металів - Частина 1: Метали, що вилучаються (дана методика також використовується для випробування важких металів в натуральній шкірі, в шкірі 3 покриттям, в текстильних килимах, пластичних масах). Метод випробувань застосовується до вилучення означених металів 3 матеріалів. Досліджувані зразки піддавали процесу екстракції кислим потовим розчином $\mathrm{pH} 5,5$ (склад: 0,5 г Lгістидину моногідрату, 5 г натрію хлориду, 2,2 г дигідрофосфату дигідрогенфосфату на 1 л води). Екстракцію проводили протягом 4 год \pm 5 хв. при $37{ }^{\circ} \mathrm{C} \pm 2{ }^{\circ} \mathrm{C}$ на водяній бані. Після завершення вилучення розчин фільтрували через мембранний фільтр розміром пор 0,45 мкм. Перед аналізом до зразків додавали 5\% азотної кислоти (об / об). Пробний тест готували відповідно до опису. Якщо після фільтрації розчин не був прозорим, то екстракційний розчин піддавався процесам мінералізації.

Методи, які використовували для визначення важких металів:

- атомно-атомна абсорбційна спектрометрія (HGAAS) - визначення Sb, As;

- атомно-абсорбційна спектрометрія 3 генерацією холодних пар (CVAAS) - визначення $\mathrm{Hg}$;

- атомно-абсорбційна спектрометрія (FAAS) визначення $\mathrm{Pb}, \mathrm{Cd}, \mathrm{Cr}, \mathrm{Co}, \mathrm{Cu}, \mathrm{Ni}$ на приладі $\mathrm{GBC}$ 908АА (рис. 2).

Результати досліджень наявності та концентрації важких металів у досліджуваних зразках матеріалів для дитячого взуття подані у табл. 3 .

3 даних табл. 3 видно, що в усіх досліджуваних матеріалах концентрація важких металів $\mathrm{Sb}, \mathrm{As}, \mathrm{Hg}$, $\mathrm{Cd}, \mathrm{Co}, \mathrm{Cr}, \mathrm{Ni}, \mathrm{Pb}$ не перевищує межі кількісного значення ГДК; у зразках 2 та 3 було виявлено мідь $(\mathrm{Cu})$; у зразках 1 та 4 - стибій $(\mathrm{Sb})$.

Висновки та перспективи подальших досліджень у даному напрямі. Отримані результати підтверджують відповідність розроблених авторами матеріалів для дитячого взуття вимогам регламенту
REACH (EC 1907/2006 - "Покращення захисту здоров'я людини та довкілля шляхом кращої та більш ранньої ідентифікації властивих властивостей хімічних речовин”) і можуть бути використані у деталях взуття для дітей. Наукова та інноваційна цінність даного дослідження полягає у використанні волокон та екстракту бамбука у матеріалах дитячого взуття шкіряного, текстильного та шкірянотекстильного, оскільки такі дослідження проведені вперше. Подальші дослідження будуть проведені на оптимальних пакетах матеріалів для дитячого взуття та демонстрації його прототипу в умовах досліджень, максимально наближених до реальних, що є когнітивною та інноваційною цінністю в даному напрямі; використані для розробки оптимальної конструкції та пакета матеріалів для взуття іншого призначення: спортивного, туристичного, спеціального тощо.

ACKNOWLEDGEMENTS: The research work has been carried out within project: "Use of bamboo extract and fibers in the elements of leather, textile and combined leather and textile children's footwear" financed by the National Centre for Research and Development (Agreement No. LIDER/16/0091/L8/16/NCBR/2017).

\section{ЛІТЕРАТУРА}

1. Toxic chemical found in school shoes. URL: https://www.smh.com.au/ healthcare/toxic-chemicalfound-in-school-shoes-20120519-1yxik.html (дата звернення 20.02.2019).

2. Toxic Exposure: Chemicals Are in Our Water, Food, Air and Furniture. URL: https://www.smh.com. au/healthcare/toxic-chemical-found-in-school-shoes20120519 - 1yxik.html (дата звернення 20.07.2019).

3. Про затвердження Державних санітарних норм та правил "Матеріали та вироби текстильні, шкіряні i хутрові. Основні гігієнічні вимоги" [Електронний ресурс]. - Режим доступу : 
https://zakon.rada.gov.ua/laws/show/z0086-13 (дата звернення 19.02.2019).

4. Kosińska B, Czerwiński K, Struszczyk MH. Safety and labelling requirements for textile products design and use aspects. FIBRES AND TEXTILES in Eastern Europe 2014; 22, 2(104): 19-24.

5. Hoath SB, Maibach HI. Neonatal skin structure and functions Second Edition. Revised and Expanded, Marcel Dekker Inc., New York 2003.

6. Fluhr JW, Pfisterer S, Gloor M. Direct comparison of skin physiology in children and adults with bioenginering methods. Pediatric Dermatology 2000; 17(6): 436-439.

7. Chajdas A, Świderska M, Daniszewska B. Prophylaxis of the healthy foot of a toddler - hygiene, exercises and massage. Family Pedagogy 2014; 4(3): 233-248.

8. Foiasi T, Pantazi M. Children's footwear health, comfort, fashion. Revista de Pielarie Incaltaminte 2010; 10 (4): 45-60.

9. Ischimji A, Malcoci M, Bulgaru V, Ischimji N, Pascari I. Studies on the functions of footwear for children. Annals of the University of Oradea 2012; 13 (1): 208-214.

10. Kristen KH, Kastner J, Holzreiter S, Wagner P, Engel A. Functional evaluation of shoes for children based on gait analysis of children in the learning to walk stage. Zeitrschrift fur Orthopadie und Ihre Grenzgebiete 1998; 136(5): 457-462.

11. Walther M, Herold D, Sinderhauf A, Morrison R. Children sport shoes - a systematic revive of current literature. Foot and Ankle Surgery 2008; 14 (4): 180-189.

12. Sekerden F. Effect of fabric weave and weft types on the characteristics of Bamboo/Cotton woven fabrics. FIBRES \& TEXTILES in Eastern Europe 2011; 19, 6(89): 47-52.

13. Kadapalayam Chinnasamy K, Chidambaram P. Influence of the Bamboo/Cotton Fibre Blend Proportion on the Thermal Comfort Properties of Single Jersey Knitted Fabrics. FIBRES \& TEXTILES in Eastern Europe 2017; 25, 6(126): 53-57. DOI: 10.5604/01.3001.0010.5371.

14. Prasanna Venkatesh R, Ramanathan K, Srinivasa Raman V. Tensile, Flexual, Impact and Water Absorption Properties of Natural Fibre Reinforced Polyester Hybrid Composites. FIBRES \& TEXTILES in Eastern Europe 2016; 24, 3(117): 90-94. DOI: $10.5604 / 12303666.1196617$.

\section{REFERENCES}

1. Pro zatverdzhennia Derzhavnykh sanitarnykh norm ta pravyl "Materialy ta vyroby tekstyl'ni, shkiriani i khutrovi. Osnovni hihiienichni vymohy", available at : https://zakon.rada.gov.ua/lavs/shov/z0086-13

2. Tokhits chemitsal found in school shoes, available at : https://vvv.smh.tsom.au/ healthtsare/ tokhits-chemitsal-found-in-school-shoes-201205191ykhik.html

3. Tokhits Ekhposure: Chemitsals Are in Our Vater, Food, Air and Furniture, available at : https://vvv.smh.tsom.au/healthtsare/tokhits-chemitsalfound-in-school-shoes-20120519-1ykhik.html

4. Kosińska B, Cherviński K and Strushchyk MH. (2014), Safety and labelling rekuirements for tekhtile produtsts - design and use aspetsts. FIBRES AND TEKhTILES in Eastern Europe; 22, 2(104): 19-24.

5. Hoath SB and Maibach HI. (2003), Neonatal skin strutsture and funtstions Setsond Edition. Revised and Ekhpanded, Martsel Dekker Ints., Nev Jork.

6. Fluhr JV, Pfisterer S and Gloor M. (2000), Diretst tsomparison of skin physiology in children and adults vith bioenginering methods. Pediatrits Dermatology; 17(6): 436-439.

7. Chajdas A, Śviderska M and Danishevska B. (2014), Prophylakhis of the healthy foot of a toddler hygiene, ekhertsises and massage. Family Pedagogy; 4(3): 233-248.

8. Foiasi T and Pantazi M. (2010), Children's footvear - health, tsomfort, fashion. Revista de Pielarie Intsaltaminte; 10 (4): 45-60.

9. Ischimi A, Maltsotsi M, Bulgaru V, Ischimi N, Pastsari I. (2012), Studies on the funtstions of footvear for children. Annals of the University of Oradea; 13 (1): 208-214.

10. Kristen Kh, Kastner J, Holzreiter S, Vagner P, Engel A. (1998), Funtstional evaluation of shoes for children based on gait analysis of children in the learning to valk stage. Zeitrschrift fur Orthopadie und Ihre Grenzgebiete; 136(5): 457-462.

11. Valther M, Herold D, Sinderhauf A, Morrison R. (2008), Children sport shoes - a systematits revive of tsurrent literature. Foot and Ankle Surgery; 14 (4): 180-189.

12. Sekerden F. (2011), Effetst of fabrits veave and veft types on the charatsteristitss of Bamboo/Tsotton voven fabritss. FIBRES \& TEKhTILES in Eastern Europe; 19, 6(89): 47-52.

13. Kadapalaiam Chinnasamy K, Chidambaram P. (2017), Influentse of the Bamboo/Tsotton Fibre Blend Proportion on the Thermal Tsomfort Properties of Single Jersey Knitted Fabritss. FIBRES \& TEKhTILES in Eastern Europe; 25, 6(126): 53-57. DOI: 10.5604/01.3001.0010.5371.

14. Prasanna Venkatesh R, Ramanathan K, Srinivasa Raman V. (2016), Tensile, Flekhual, Impatst and Vater Absorption Properties of Natural Fibre Reinfortsed Poliester Hybrid Tsomposites. FIBRES \& TEKhTILES in Eastern Europe; 24, 3(117): 90-94. DOI: $10.5604 / 12303666.1196617$.

Стаття надійшла до редакиії 13 березня 2019 р. 